\title{
Nutritional recovery with rice bran did not modify energy balance and leptin and insulin levels
}

\author{
Recuperação nutricional com farelo de arroz não modificou \\ o balanço energético e os níveis de leptina e insulina
}

Maria Salete F. Martins', Lila M. Oyama², Marcia Q. Latorraca',

Maria Helena G. Gomes-da-Silva', Claudia M. O. Nascimento

\begin{abstract}
Objective: To investigate the effect of nutritional recovery with rice bran on energy balance, leptin and insulin levels. Methods: Weaned Wistar rats were fed on a $17 \%$ (Control $-\mathrm{C}$ ) or $0.5 \%$ (Aproteic - A) protein diet for $12 \mathrm{~d}$. After this, rats were kept on a $\mathrm{C}$ diet $(\mathrm{C})$ or recovered with control (Recovered Control - $\mathrm{RC}$ ) or control plus recovered rice bran diet (Recovered Rice Bran RRB). Results: Despite the increased food intake, group A exhibited lower carcass fat associated to low serum leptin. RRB and RC groups showed lower carcass weight and energy intake and expenditure. Energy expenditure was positively associated with food intake and carcass weight. Negative correlations between HOMA-IR and energy expenditure and energy intake were observed. Conclusion: Nutritional recovery with rice bran did not modify energy balance, leptin and insulin levels. Arq Bras Endocrinol Metab. 2010;54(3):289-94
\end{abstract}

\section{Keywords}

Energy balance; leptin; insulin; rice bran; nutritional recovery

\section{RESUMO}

Objetivo: Investigar o efeito da recuperação nutricional com farelo de arroz sobre o balanço energético e níveis de leptina e insulina. Métodos: Ratos Wistar recém-desmamados foram alimentados com 17\% (Controle - C) ou 0,5\% (Aproteico - A) de proteína (caseína) durante 12 dias. Em seguida, ratos permaneceram com dieta controle $(C)$ ou foram recuperados com controle (Recuperados Controle - RC) ou controle mais 5\% de farelo de arroz (Recuperados com Farelo de Arroz - RFA) durante 21 dias. Resultados: Apesar de a ingestão alimentar ter sido maior em A, a gordura na carcaça foi reduzida, sendo associada com menor nível de leptina. Os grupos RFA e RC tiveram redução no peso da carcaça, no gasto e ingestão de energia. 0 gasto energético foi correlacionado com a ingestão de alimentos e o peso da carcaça fresco. Foi observada correlação negativa entre HOMA-IR com gasto energético e com ingestão de energia.

Correspondence to: Maria Salete F. Martins Departamento de Alimentos e Nutrição, Faculdade de Nutrição, UFMT

Av. Fernando Correa da Costa, s/n 78060-900 - Cuiabá, MT, Brasil msfm@terra.com.br nem os níveis de leptina e insulina. Arq Bras Endocrinol Metab. 2010;54(3):289-94

\section{Descritores}

Balanço energético; leptina; insulina; farelo de arroz; recuperação nutricional

\section{INTRODUCTION}

$\mathrm{T}$ the prevalence of obesity has increased dramatically over the past few decades and diet composition is one of the factors that can influence its development (1). High-fat, high-sucrose and varied "cafeteria" diets may induce obesity $(2,3)$. Moreover, it has been suggested that rats fed low-protein diets that showed ra- pid development of hyperphagia, increased body fat and elevated circulating leptin concentrations may be an important animal model of diet-induced obesity in humans (4). Interestingly, rats recovered from undernutrition exhibit greater proportion of fat in the body compared with those maintained with normal plane of nutrition throughout life (5). 
In Brazil the use of some non-conventional foods called "multi-mixture" is disseminated to recover malnourished children, and rice bran is one of their constituents. Rice bran contains high levels of protein, mineral (6) and lipids, consequently high energy content. Studies have shown that the aminoacid composition of rice bran is the best among cereals. Moreover, this cereal is an important source of dietary fiber $(7,8)$.

Dietary fiber has been proven to be an efficient tactic to prevent obesity, because it reduces energy intake by inducing satiation and satiety $(9,10)$ and decreases the energy density by lowering digestibility (11). The addition of fibers that form viscous colloidal dispersions when hydrated affects multiple aspects of gastrointestinal functions, such as gastric emptying, small bowel transit time, and the digestion and absorption of nutrients, particularly fat and carbohydrate $(12,13)$.

Due to its elevated nutritional value and significant fiber content, that exert a beneficial role in the prevention of obesity, rice bran could be an excellent alternative feed in the recovery of the nutritional status in an animal model with tendency to body fat accumulation. Thus, firstly we examined whether severe protein malnutrition during the growth phase after weaning is a risk factor for the development of obesity. Secondly we examined, if nutritional recovery with rice bran changes body composition, energy balance and leptin and insulin levels. Finally, because insulin and leptin regulate food intake and energy expenditure we verified the relationship of these hormones and the homeostasis model assessment - insulin resistance (HOMA-IR) index with these components of energy balance.

\section{MATERIALS AND METHODS}

\section{Animals and diets}

All animal experiments were approved by the Federal University of São Paulo Ethics Committee (São Paulo, Brazil) (Proc. $\mathrm{N}^{\circ}$ 0305). Twenty nine weaned male Wistar rats (21 days old and weighing 40-50 g) were obtained from the University's own breeding colony, randomly separated in individual cages and kept under standard lighting conditions (12-h light/dark cycle) at a temperature of $24 \pm 1^{\circ} \mathrm{C}$. Throughout the experimental period rats were given free access to food and water. During the first stage of experimentation (12 days), rats $(n=6)$ received a control diet containing $17 \%$ protein (Control - C group) or a $0.5 \%$ protein diet (Aproteic
- A group). In the second stage, group A was randomized to recover during 21 days with either the control $\operatorname{diet}$ (Recovered Control - RC group, $\mathrm{n}=5$ ) or control diet plus $5 \%$ of rice bran (Recovered Rice Bran - RRB group, $\mathrm{n}=6$ ), and the control group was maintained in the control diet (C group, $\mathrm{n}=6$ ) (14). Rice bran contained $2.3 \%$ water, $16.85 \%$ protein, $9.46 \%$ lipids, $56.5 \%$ carbohydrate, $11.32 \%$ fiber ( $80 \%$ insoluble, $20 \%$ soluble), and $3.56 \%$ ash (15-17). Rats were weighed twice per week, and food intake was measured daily.

\section{Biological methods for evaluation of diets}

For evaluation of the biological value of the ratios the following indices were used: 1) Protein efficiency ratio (PER) was determined by the following formula: PER = weight gain $(\mathrm{g}) /$ protein intake $(\mathrm{g}) ; 2)$ Digestibility $(\%)(D)=[($ Nitrogen intake-Fecal nitrogen $) /$ Nitrogen intake $]$ x100 (18). The fecal nitrogen was determined by Micro-Kjeldahl method (15).

\section{Sample collection and analysis}

At the end of the experimental period and after overnight fasting, rats were killed by decapitation, and their liver and spleen were removed and weighed. The entire carcasses were eviscerated and frozen for subsequent body composition analysis. Blood samples were collected, serum was obtained by centrifugation and aliquots were used to measure serum glucose by the oxidase-peroxidase method (19), total serum protein by the biuret-modified method (20), serum albumin by the green bromocresol method (21), using commercial kits (Labtest Diagnóstica, Brazil). Commercial radioimmunoassay kits were used to determine serum insulin (Coat-A-Count DPC MedLab, CA, USA) and serum leptin (Linco Research, Inc, MO, USA) concentrations. The physiological index of insulin resistance used was HOMA-IR (22), assessed from fasting glucose and fasting insulin concentrations using the following formula: fasting insulin $(\mu \mathrm{U} / \mathrm{mL}) \mathrm{x}$ fasting glucose $(\mathrm{mmol} / \mathrm{L}) / 22.5$.

\section{Measurement of carcass composition and energy intake}

In brief, the eviscerated carcasses were shaved, autoclaved, and homogenized with a Polytron homogenizer. Percent body fat mass was determined by the method of Folch and cols. (23) and protein percent was determined as described by Leshner and cols. (24). 
To calculate energy intake, we considered the energy content of protein and carbohydrate to be 16.74 $\mathrm{kJ} / \mathrm{g}$, and of fat to be $37.7 \mathrm{~kJ} / \mathrm{g}(4)$. The body energy content was calculated from the amount of fat and protein using constants $40 \mathrm{~kJ} / \mathrm{g}$ fat and $24 \mathrm{~kJ} / \mathrm{g}$ protein. To calculate carcass composition before the recovery stage (initial carcass energy) data from rats under similar dietary treatments were used. From the difference between the final carcass composition and the initial carcass composition residual lipid balance, protein balance, energy balance, energy efficiency [(energy gain/energy intake)x100] and energy expenditure (difference between energy intake and energy gain) were calculated.

\section{Statistical analysis}

Results were expressed as mean \pm SEM for the number of rats indicated. Groups C and A were compared with unpaired $t$-tests. One-way analysis of variance was used to compare data from the control (C), recovered control (RC) and recovered rice bran (RRB) groups. When necessary, these analyses were complemented by Tukey test to determine the significance of individual differences. Levene's test for homogeneity of variances was initially used to determine whether data complied with the assumptions of parametric analysis of variance. When necessary, data were log-transformed to correct for variance in heterogeneity or non-normality (25). The Pearson correlation coefficient was used to examine the relationship between energy intake and energy expenditure, between fresh carcass weight and energy expenditure, between HOMA-IR and energy expenditure, between fresh carcass weight and energy intake, between HOMA-IR and energy intake. A p $<0.05$ indicated statistical significance. All statistical comparisons were performed using the Statistics software package (Statsoft, Tulsa, OK, USA).

\section{RESULTS}

After twelve days on an aproteic diet group A's carcass weight corresponded to $48 \%$ of group C's carcass weight. Despite the reduction observed in the whole protein content, its proportion was similar in both groups. The absolute and relative amount of body lipid was lower in group A than in group C. Serum total protein, albumin, leptin and insulin concentrations were reduced in A as compared to group C. Only serum glucose levels were similar between groups (Table 1 ).
Table 1. Carcass composition, serum concentration of total protein, albumin, glucose, insulin and leptin of rats weaned and maintained for 12 days with $\mathrm{C}$ (Control) or A (Aproteic) diet

\begin{tabular}{lccc}
\hline Variables & $\mathbf{C ~ ( n = 6 )}$ & $\mathbf{A ~ ( n = 6 )}$ & $\mathbf{P}$ \\
\hline Fresh carcass $(\mathrm{g})$ & $94.0 \pm 2.8$ & $45.2 \pm 1.4$ & $\mathrm{P}<0.001$ \\
Protein $(\mathrm{g})$ & $15.4 \pm 0.5$ & $5.2 \pm 0.3$ & $\mathrm{P}<0.001$ \\
Protein (g/100 g carcass weight) & $16.5 \pm 0.5$ & $17.0 \pm 0.7$ & $\mathrm{P}>0.05$ \\
Lipid $(\mathrm{g})$ & $4.9 \pm 0.6$ & $0.7 \pm 0.1$ & $\mathrm{P}<0.001$ \\
Lipid $(\mathrm{g} / 100 \mathrm{~g}$ carcass weight) & $5.9 \pm 0.7$ & $2.3 \pm 0.3$ & $\mathrm{P}<0.001$ \\
Total protein (g/dL) & $5.87 \pm 0.09$ & $4.37 \pm 0.12$ & $\mathrm{P}<0.001$ \\
Albumin $(\mathrm{g} / \mathrm{dL})$ & $3.10 \pm 0.07$ & $2.20 \pm 0.05$ & $\mathrm{P}<0.001$ \\
Glucose $(\mathrm{mg} / \mathrm{dL})$ & $76.86 \pm 2.91$ & $67.68 \pm 4.66$ & $\mathrm{P}>0.05$ \\
Insulin $(\mu \mathrm{U} / \mathrm{mL})$ & $16.84 \pm 2.95$ & $<4.0$ & $\mathrm{P}<0.001$ \\
Leptin $(\mathrm{ng} / \mathrm{mL})$ & $0.69 \pm 0.10$ & $0.39 \pm 0.004$ & $\mathrm{P}<0.05$ \\
\hline
\end{tabular}

Data are reported as means \pm SEM. Student's independent $t$-test.

Similar protein intake and protein digestibility in both RC and RRB groups was observed, but it was significantly lower when compared to group C. Protein efficiency did not differ in RC and RRB groups, but it was increased in relation to group C (Table 2).

Table 2. Protein intake $(\mathrm{g})$, relative digestibility and protein efficiency of rats weaned and maintained with $\mathrm{C}$ (Control) and recovered for $21 \mathrm{~d}$ with $\mathrm{RC}$ (Recovered Control) or with RRB (Recovered Rice Bran)

\begin{tabular}{lccc}
\hline Variables & $\mathbf{C ~ ( n = 6 )}$ & RC $(\mathbf{n}=\mathbf{5})$ & RRB $(\mathbf{n = 6})$ \\
\hline Protein intake & $64 \pm 2^{\mathrm{b}}$ & $46 \pm 1^{\mathrm{a}}$ & $46 \pm 1^{\mathrm{a}}$ \\
Relative digestibility & $98 \pm 0.2^{\mathrm{b}}$ & $93 \pm 0.7^{\mathrm{a}}$ & $92 \pm 0.5^{\mathrm{a}}$ \\
Protein efficiency & $1.7 \pm 0.08^{\mathrm{a}}$ & $2.8 \pm 0.02^{\mathrm{b}}$ & $2.9 \pm 0.05^{\mathrm{b}}$ \\
\hline
\end{tabular}

Values are means \pm SEM for the number of rats in parentheses. Means with different superscript letters are significantly different by one-way ANOVA followed by Tukey test $(p<0.05)$.

Fresh carcass weights from the RC and RRB groups were similar and significantly lower than in the group C. In the RRB group the total carcass protein content was decreased compared to group $\mathrm{C}$ and equal to the RC group. The lipid content in the RC and in $\mathrm{RRB}$ groups was lower than in group C. However, the proportion of protein and lipids were not different among groups.

Total energy intake, energy expenditure, initial and final carcass energy were similar in the recovery groups and significantly lower when compared to group C. Energy gain from protein, total energy gain and energy efficiency were not influenced by the treatment. Energy gain from lipids in RC rats was greater than in C, whereas in $\mathrm{RRB}$ rats there was no significant difference as compared to the two other groups (Table 3 ). 
Table 3. Carcass composition and energy balance of rats weaned and maintained with $\mathrm{C}$ (Control) and recovered for 21d with $\mathrm{RC}$ (Recovered Control) or with RRB (Recovered Rice Bran)

\begin{tabular}{lccc}
\hline Variables & $\mathbf{C}(\mathbf{n}=\mathbf{6})$ & $\mathbf{R C}(\mathbf{n}=\mathbf{5})$ & RRB $(\mathbf{n}=\mathbf{5})$ \\
\hline Fresh carcass (g) & $196 \pm 2^{\mathrm{b}}$ & $129 \pm 9^{\mathrm{a}}$ & $135 \pm 8^{\mathrm{a}}$ \\
Protein (g) & $35 \pm 1^{\mathrm{b}}$ & $30 \pm 2^{\mathrm{ab}}$ & $29 \pm 1^{\mathrm{a}}$ \\
Protein (g/100 g carcass weight) & $16 \pm 0.4$ & $18 \pm 0.8$ & $17 \pm 0.9$ \\
Lipid (g) & $27 \pm 1.6^{\mathrm{b}}$ & $18 \pm 1.7^{\mathrm{a}}$ & $19 \pm 2.5^{\mathrm{a}}$ \\
Lipid (g/100 g carcass weight) & $13 \pm 0.8$ & $11 \pm 0.7$ & $11 \pm 0.9$ \\
Energy intake (kJ) & $7677 \pm 98^{\mathrm{b}}$ & $5115 \pm 32^{\mathrm{a}}$ & $5148 \pm 56^{\mathrm{a}}$ \\
Initial carcass energy (KJ) & $601 \pm 13^{\mathrm{b}}$ & $153 \pm 4^{\mathrm{a}}$ & $157 \pm 8^{\mathrm{a}}$ \\
Final carcass energy (kJ) & $1751 \pm 79^{\mathrm{b}}$ & $1094 \pm 72^{\mathrm{a}}$ & $1170 \pm 105^{\mathrm{a}}$ \\
Energy gain (kJ) & $1160 \pm 83$ & $941 \pm 73$ & $1013 \pm 102$ \\
Gain as protein (KJ) & $386 \pm 22$ & $418 \pm 29$ & $435 \pm 44$ \\
Gain as lipid (KJ) & $775 \pm 73^{\mathrm{b}}$ & $523 \pm 49^{\mathrm{a}}$ & $579 \pm 78^{\mathrm{ab}}$ \\
Energy expenditure (KJ) & $6517 \pm 86^{\mathrm{b}}$ & $4174 \pm 84^{\mathrm{a}}$ & $4134 \pm 137^{\mathrm{a}}$ \\
Energy efficiency & $15 \pm 1$ & $18 \pm 1$ & $20 \pm 2$ \\
\hline
\end{tabular}

Values are means \pm SEM for the number of rats in parentheses. Means with different superscript letters are significantly different by one-way ANOVA followed by Tukey test $(p<0.05)$.

Energy expenditure was directly correlated with energy intake $\left(\mathrm{r}^{2}=0.974, \mathrm{P}<0.0001\right)$ and fresh carcass weight $\left(\mathrm{r}^{2}=0.569, \mathrm{P}<0.0001\right)$, but inversely correlated with HOMA-IR $\left(\mathrm{r}^{2}=0.314, \mathrm{P}<0.01\right)$ (Figure 1A, $\mathrm{IB}$ and $\mathrm{lC})$. Also, there was a significant positive correlation between energy intake and fresh carcass weight $\left(\mathrm{r}^{2}=0.809, \mathrm{P}<0.0001\right)$ (Figure $\left.\mathrm{ID}\right)$ as well as a negative correlation between energy intake and HOMA-IR $\left(\mathrm{r}^{2}=0.261, \mathrm{P}<0.02\right)$ (Figure $\left.\mathrm{IE}\right)$. Correlations were absent for energy expenditure and energy intake, and serum insulin and leptin levels.

\section{DISCUSSION}

In this study, weaned rats, when submitted to an aproteic diet for twelve days, displayed typical features of malnutrition, such as reduced carcass mass, hypoproteinaemia and hypoalbuminaemia. Also, reduced absolute energy intake but increased energy intake in proportion to body mass (data not shown) was observed, which can be explained by the preserved proportion of carcass protein.

Nevertheless, despite the increased food intake, our animals did not exhibit body fat accumulation as reported in other studies $(4,26)$ but, as expected, this lower carcass lipid content was associated to low serum leptin levels. Reduced carcass lipids in our proteinrestricted animals possibly resulted from an increased activity of brown adipose tissue associated to adaptative diet-induced thermogenesis $(27,28)$ that dissipated the excess of energy intake (28).
Increased sympathetic activity and thermogenesis may inhibit insulin release (29) and simultaneously stimulate glucose transport (30). The hypoinsulinaemia and euglycemia exhibited by our rats from the aproteic group reinforce the hypothesis of increased sympathetic activity and thermogenesis in this animal model. However, this hypothesis is attenuated if one considers that murine leptin deficiency is accompanied by hypometabolism and decreased sympathetic activity (31) in mice (32).

Rats recovering from malnutrition with rice bran or on control diets showed a lower carcass weight as compared to control rats, despite the similar energy gain. Although the RC group had exhibited lower lipid gain than group $\mathrm{C}$, the proportion of carcass lipids was equal in all groups. In addition, all groups had similar protein and proportion of carcass protein gains. These results are partially in agreement with the observation that under restricted nutritional conditions followed by recovery, the proportion of lean mass does not change, but the proportion of fat tissue increases (5). However, elevated adiposity after nutritional rehabilitation has been evidenced in models of caloric restriction and our rats were maintained on an aproteic diet.

Relative protein digestibility in the RRB and RC groups was similar and lower than in group C, probably due to permanent damages resulting from the severe protein restriction imposed during critical development phase. This supposition is reinforced by the observation that malnutrition has dramatic effects on small intestinal mucosal structure and transport activity, reducing the specific aminoacid absorption that remains impaired even after nutritional recovery (33). Curiously, the recovered groups that had lower protein digestibility demonstrated higher protein efficiency and equal energy efficiency. Taking into consideration that protein efficiency was calculated from the total body weight gain (including water) and energy efficiency was based on energy gain from protein and lipids, it is possible that the first variable had been overestimated.

Energy expenditure and energy intake in the RRB and $\mathrm{RC}$ rats were reduced when compared to control rats, but these variables did not correlate with serum insulin or leptin levels. Energy expenditure was strongly associated with food intake and fresh carcass weight. Positive association between food intake and energy expenditure results from diet-induced thermogenesis that recognizably varies with energy ingested as well as with macronutrient composition (34). The relationship between energy expenditure and body weight is remark- 
(A)

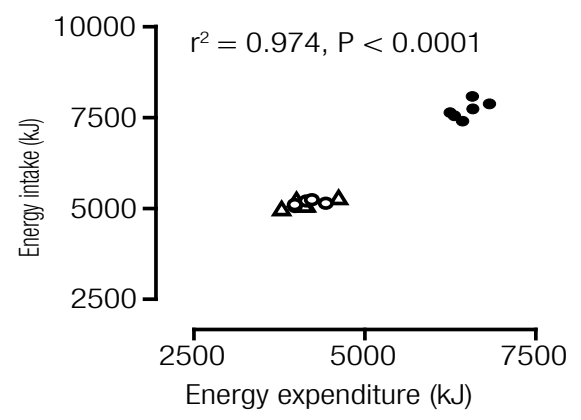

(C)

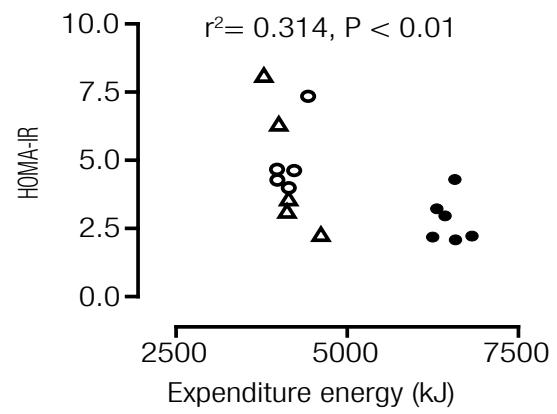

(B)

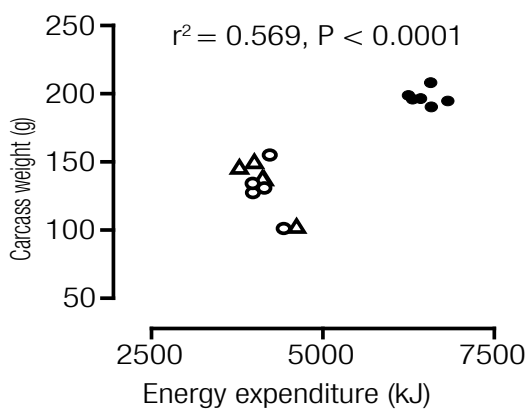

(D)

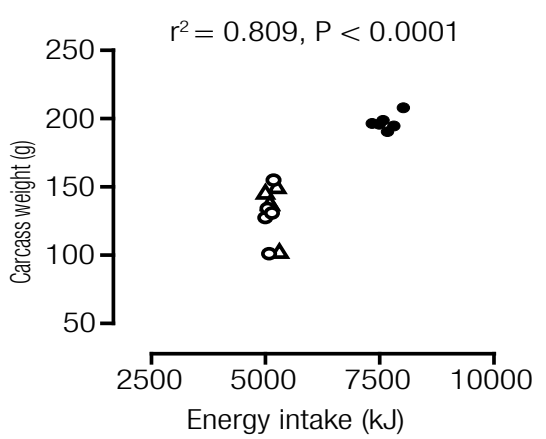

(E)

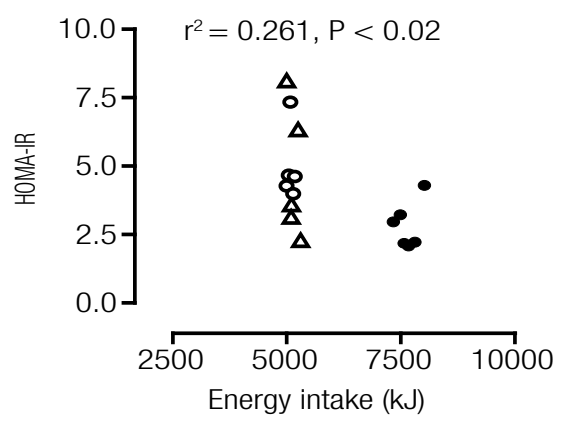

C (• closed circle), RC (o open circle), RRB ( $\Delta$ open triangle).

Figure 1. Correlation between energy expenditure and energy intake (A), energy expenditure and carcass weight (B), energy expenditure and HOMA-IR (C), energy intake and carcass weight (D) and HOMA-IR and energy intake (E) of C, RC and RRB groups.

ably consistent in a wide range of animal species (35) and body area has been used as the unit that traditionally expresses basal metabolism, based on the supposition that body heat loss is proportional body surface (36).

There was a negative correlation between HOMAIR and energy expenditure, i.e., recovered rats that tended to be more insulin resistant showed low energy expenditure. This observation agrees with the reports that insulin increases sympathetic neural activity and energy expenditure $(37,38)$. Unexpectedly, although weak, there was also an inverse relationship between HOMA-IR and energy intake. Thus, recovered rats that were insulin resistant ate more than the control rats that showed higher insulin sensitivity. The literature supports the hypothesis that insulin resistance may impair regulation of energy intake and at least in obese animals, insulin resistance leads to greater energy intake $(39,40)$.

In conclusion, our results indicate that severe protein restriction during growth phase after weaning did not contribute to the manifestation of obesity. Body composition, energy balance and both leptin and insulin levels were not modified by nutritional recovery with rice bran. Finally, the expected modulator role of insulin and leptin in food intake and energy expenditure was not verified. 
Acknowledgements: The authors acknowledge Celso Roberto Afonso for his technical assistance, and the National Council of Research (CNPq) for financial support.

Disclosure: no potential conflict of interest relevant to this article was reported.

\section{REFERENCES}

1. Geloneze B, Mancini MC, Coutinho W. Obesity: knowledge, care, and commitment, but not yet cure. Arq Bras Endocrinol Metabol. 2009;53:117-9.

2. Rothwell NJ, Stock MJ. The development of obesity in animals: the role of dietary factors. Clin Endocrinol Metab. 1984;13:437-49.

3. Eguchi R, Cheik NC, Oyama LM, Oller do Nascimento CM, de Mello MT, Tufik S, et al. Efeitos do exercício crônico sobre a concentração circulante da leptina e grelina em ratos com obesidade induzida por dieta. Rev Bras Med Esporte. 2008;14:182-7.

4. Du F, Higginbotham DA, White BD. Food intake, energy balance and serum leptin concentrations in rats fed low-protein diets. J Nutr. 2000;130:514-21.

5. Harris PM, Widdowson EM. Deposition of fat in the body of the rat during rehabilitation after early undernutrition. $\mathrm{Br} \mathrm{J}$ Nutr. 1978;39:201-11.

6. Barbosa CO, Lopes IBM, Morgano MA, Araújo MAM, MoreiraAraújo RSR. Conteúdo de minerais dos ingredientes e da multimistura. Ciênc Tecnol Aliment (Campinas). 2006;26(4):916-20.

7. Santana LFR, Costa NMB, Oliveira MGA, Gomes MRA. Valor nutritivo e fatores antinutricionais de multimisturas utilizadas como alternativa alimentar. Braz J Food Technol. 2000;3:129-35.

8. Glória ECS, Almeida NAV, Costa ASV, Junior EH, Martins SL, Paula $\mathrm{H}$, et al. Avaliação protéica de uma nova multimistura com base no milho QPM BR 473. Rev Nutr. 2004;17(3):379-85.

9. Mello VD, Laaksonen DE. Fibra na dieta: tendências atuais e benefícios à saúde na síndrome metabólica e no diabetes melito tipo 2. Arq Bras Endocrinol Metabol. 2009;53-5.

10. Lyly M, Liukkonen KH, Salmenkallio-Marttila M, Karhunen L, Poutanen K, Lähteenmäki L. Fibre in beverages can enhance perceived satiety. Eur J Nutr. 2009;48(4):251-8.

11. Eggum BO, Thorbek G, Beames RM, Chwalibog A, Henckel S. Influence of diet and microbial activity in the digestive tract on digestibility, and nitrogen and energy metabolism in rats and pigs. Br J Nutr. 1982;48(1):161-75.

12. Vahouny GV, Satchithanandam S, Chen I, Tapper SA, Kritchevsky D, Lightlot FG, et al. Dietary fiber and intestinal adaptation: effects on lipid absorption and lymphatic transport in the rat. Am J Clin Nutr. 1988;47:201-6.

13. Juvonen KR, Purhonen AK, Salmenkallio-Marttila M, Lähteenmäki $L$, Laaksonen DE, Herzig KH, et al. Viscosity of oat bran-enriched beverages influences gastrointestinal hormonal responses in healthy humans. J Nutr. 2009;139(3):461-6.

14. Reeves PG, Nielsen FH, Fahey GC Jr. AIN-93 purified diets for laboratory rodents: final report of the American Institute of Nutrition ad hoc writing committee on the reformulation of the AIN76A rodent diet. J Nutr. 1993;123(11):1939-51.

15. Association Official Analytical Chemists. Official Methods of Analysis. 1995; 16. ed. Arlington: AOAC.

16. Asp NG, Johnansson CG, Hallmer H, Siljestrom M. Rapid enzymatic assay of insoluble and soluble dietary fibre. J Agric Food Chem. 1983;1:476-82.

17. Instituto Adolfo Lutz - IAL. Normas Analíticas do Instituto Adolfo Lutz. Métodos químicos e físicos para análise de alimentos. 3.ed. São Paulo: IMESP; 1985. p. 21-4.

18. Boza JJ, Jimenez J, Martinez O, Suarez MD, Gil A. Nutritional value and antigenicity of two milk protein hydrolysates in rats and guinea pigs. J Nut. 1994;124(10):1978-86.
19. Trinder P. Determination of blood glucose using an oxidase-peroxidase system with a non-carcinogenic chromogen. J Clin Path. 1969;22:158-61.

20. Wolfson WQ, Cohn C, Calvary F, Ichiba F. Studies in serum proteins. A rapid procedure for the estimation of total protein true albumin, total globulin, alpha globulin and gamma globulin in 1.0 $\mathrm{mL}$ of serum. Am J Clin Pathol. 1948;18:723-30.

21. Doumas BT, Watson WA, Biggs HG. Albumin standards and measurements of serum albumin with bromocresol green. Clin Chim Acta. 1971;31:87-96.

22. Matthews DR, Hosker JP, Rudenski AS, Naylor BA, Treacher DF, Turner RC. Homeostasis model assessment: insulin resistance and beta-cell function from fasting plasma glucose and insulin concentrations in man. Diabetol. 1985;28:412-9.

23. Folch J, Lees M, Stanley GHS. A simple method for the isolation and purification of total lipids from animal tissues. J Biol Chem. 1957;226:497-509.

24. Leshner Al, Litwin VA, Squibb RL. A simple method for carcass analysis. Physiol Behav. 1972;9:281-2.

25. Sokal RR, Rohlf FJ. Biometry: the principles and practice of statistics in biological research. New York: WH Freeman and Company; 1995. p. 392-450.

26. White BD, Porter $\mathrm{MH}$, Martin RJ. Protein selection, food intake, and body composition in response to the amount of dietary protein. Physiol Behav. 2000;69:383-9.

27. Rothwell NJ, Stock MJ. Influenced of carbohydrate and fat intake on diet-induced thermogenesis and brown fat activity in rats fed low protein diets. J Nutr. 1987;117(10):1721-6.

28. Cannon B, Nedergaard J. Brown adipose tissue: function and physiological significance. Physiol Rev. 2004;84(1):277-359.

29. Baroody GM, Howland RJ. Insulin secretion by the perfused pancreas of the cold- acclimated rat. Can J Physiol Pharmacol. 1980;58:1426-30.

30. Aparecida de França S, dos Santos MP, Garófalo MAR, Navegantes LC, Kettelhut IC, Lopes CF, et al. Low protein diet changes the energetic balance and sympathetic activity in brown adipose tissue of growing rats. Nutrition. 2009;1186-92.

31. Montez JM, Soukas A, Asilmaz E, Fayzikhodjaeva G, Fantuzzi G, Friedman JM. Acute leptin deficiency, leptin resistance, and the physiological response to leptin withdrawal. Proc Natl Acad Sci. 2005;102:2537-42.

32. Huang K, Rabold R, Abston E, Schofield B, Misra V, Galdzicka E, et al. Effects of leptin deficiency on postnatal lung development in mice. J Appl Physiol. 2008;105:249-59.

33. Ventrucci G, Ramos SLG, Roston MMA, Gomes MMC. Effects of a leucine-rich diet on body composition during nutritional recovery in rats. Nutrition. 2004;20:213-7.

34. Riggs AJ, White BD, Gropper SS. Changes in energy expenditure associated with ingestion of high protein, high fat versus high protein, low fat meals among underweight, normal weight, and overweight females. J Nutr. 2007;12:6-40.

35. Kleiber M. Body size and metabolic rate. Physiol Rev. 1947;15:511-41.

36. Dubois D, Dubois EF. Clinical calorimetry. The formula to estimate the approximate surface area if height and weight be known. Arch Inter Med. 1916;17:863.

37. Plum L, Belgardt BF, Brüning JC. Central insulin action in energy and glucose homeostasis. J Clin Invest. 2006;116(7):1761-6.

38. Velloso LA. O controle hipotalâmico da fome e da termogênese - Implicações no desenvolvimento da obesidade. Arq Bras Endocrinol Metabol. 2006;50(2):165-76.

39. Han JC, Rutledge MS, Kozlosky M, Salaita CG, Gustafson JK, Keil $M F$, et al. Insulin resistance, hyperinsulinemia, and energy intake in overweight children. J Pediatr. 2008;152(5):612-7.

40. Nascimento AF, Sugizaki MM, Leopoldo AS, Lima-Leopoldo AP, Luvizotto RA, Nogueira CR, et al. A hypercaloric pellet-diet cycle induces obesity and co-morbidities in Wistar rats. Arq Bras Endocrinol Metabol. 2008;52(6):968-74. 